\title{
Production of Marker-free Transgenic Rice (Oryza sativa L.) with Improved Nutritive Quality Expressing AmA1
}

\author{
Ming Xu, Shuai Zhao, Yuwen Zhang, Hengjie Yin, Xuejuan Peng, Zuxin Cheng, Zhijian Yang, Jingui Zheng* \\ Crop Quality Institute, College of Crop Science, Fujian Agriculture and Forestry University, Fuzhou 350002, P.R. China \\ ${ }^{*}$ Corresponding author: Jingui Zheng, Crop Quality Institute, College of Crop Science, Fujian Agriculture and Forestry University, Fuzhou 350002, P.R. \\ China.Tel/Fax:+86-591-83789231; E-mail: jgzheng@fafu.edu.cn
}

Received: 18 March 2016; $\quad$ Revised: 12 Oct. 2016; Accepted: 20 June 2017; $\quad$ Published online: 19 August 2017

\begin{abstract}
Background: Rice seed proteins are lacking essential amino acids (EAAs). Genetic engineering offers a fast and sustainable method to solve this problem as it allows the specific expression of heterologous EAA-rich proteins. The use of selectable marker gene is essential for generation of transgenic crops, but might also lead to potential environmental and food safety problems. Therefore, the production of marker-free transgenic crops is becoming an extremely attractive alternative and could contribute to the public acceptance of transgenic crops.

Objectives: The present study was conducted to examine whether AmA1 can be expressed specifically in rice seeds, and generate marker-free transgenic rice with improved nutritive value.

Materials and Methods: $A m A 1$ was transferred into rice using Agrobacterium-mediated co-transformation system with a twin T-DNA binary vector and its integration in rice genome was confirmed by southern blot. Transcription of AmAl was analyzed by Real-Time PCR and its expression was verified by western analysis. Protein and amino acid content were measured by the Kjeldahl method and the high-speed amino acid analyzer, respectively.

Results: Five selectable marker-free homozygous transgenic lines were obtained from the progeny. The expression of recombinant AmA1 was confirmed by the observation of a $35 \mathrm{kDa}$ band in SDS-PAGE and western blot. Compared to the wild-type control, the total protein contents in the seeds of five homozygous lines were increased by $1.06 \sim 12.87 \%$. In addition, the content of several EAAs, including lysine, threonine, and valine was increased significantly in the best expressing line.

Conclusions: The results indicated that the amino acid composition of rice grain could be improved by seed-specific expression of AmA1.

Keywords: AmA1 gene; Co-transformation; Essential amino acid; Selectable marker-free; Rice.
\end{abstract}

\section{Background}

Rice (Oryza sativa L.) is amongst important crops and the staple food for over half the world's population (1), and also main source of protein and energy of the people in South East Asia $(1,2)$. However, like other cereals, rice proteins are incomplete in nutrition value due to the deficiency in certain essential amino acids (EAAs), such as lysine, threonine and methionine (3$5)$. Due to limited availability of genetic resources for genetic breeding, and the fact that genetic traits for high contents of lysine, or methionine are generally associated with abnormal plant growth, attempts at improving the EAAs content of rice through conventional breeding had little success (4). Genetic engineering approaches seem to be more promising to improve the EAAs content of rice grains, as it allows the specific expression of certain EAA-rich proteins (4, $6,7)$, such as pea lysine-rich legumin (8), winged bean lysine-rich protein WBLRP (9), potato glutamic acidrich protein GARP (10), sunflower sulfur-rich albumin SFA8 (11), and sesame methionine-rich albumin S2AS (12).

The AmA1 seed albumin from the pseudo-cereal Amaranthus hypochondriacus is rich in all EAAs, and unlike Brazil nut 2S albumin, it is non-allergenic (13). Chakraborty et al. (14) expressed AmA1 in potato 
tuber, resulting in a significant increase in most EAAs, such as methionine, lysine, cysteine and tyrosine, and the protein content was also increased by $35 \sim 45 \%$, compared with the untransformed counterpart. Furthermore, the data on safety evaluation indicated that the AmAl-transgenic potato tubers are nontoxic, nonallergenic, and safe to consume (15). Thomas et al. (16) reported the expression of $A m A 1$ in wheat seeds, using a powerful wheat endosperm-specific promoter, and an increase in both total protein and EAA levels were also noted. To the best of our knowledge, there is limited information so far on AmA1 use in improving the EAA composition of staple rice.

Selectable marker genes (SMGs), such as antibiotic or herbicide resistance genes, are used in nearly every plant transformation protocol to efficiently distinguish transformed from non-transformed shoots (lines). However, once transgenic plants are regenerated, SMGs generally serve no useful purpose. On the contrary, the continued presence of SMGs in transgenic plants may raise public and regulatory concerns on their biosafety $(17,18)$. Rice is one of genetically modified crops at the earliest stage, however, most of the existing transgenic rice lines generated with improved nutritive carry the SMGs, especially antibiotic resistance genes (8-12), that would limit the commercialization and dissemination of transgenic rice for agricultural production. Several approaches have been developed to remove SMGs from transgenic plants $(19,20)$. Among these, the cotransformation system appears to be the simplest and could be suitable for most important crops (19).

\section{Objectives}

The aim of the present work was to examine whether AmA1 can be expressed specifically in the seeds of rice, and generate SMG-free transgenic rice with improved nutritive value using Agrobacterium-mediated cotransformation system with a twin T-DNA binary vector.

\section{Materials and Methods}

\subsection{Plasmid Construct}

The twin T-DNA binary plasmid vector pCDMARAmA1-hpt (Fig. 1), was previously constructed in our laboratory (21), which was composed of two transferring DNA region. One of T-DNA region contains the chimeric gene pGt1-AmA1-nos, carrying the 915 bp desired AmAl coding region (13), $1314 \mathrm{bp}$ seed-specific Gt1 promoter (22) and nopaline synthase (nos) terminator. The chimeric gene is flanked by 1.0

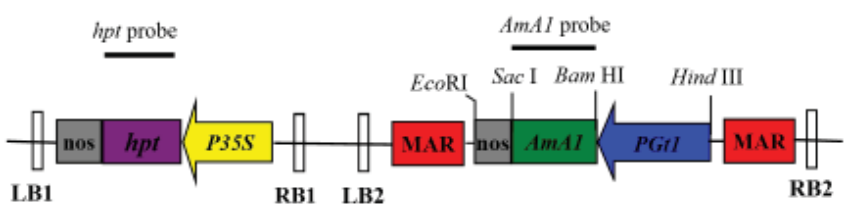

Figure 1. The T-DNA structure of binary plasmid vectors pCDMAR AmA1-hpt. hpt= hygromycin phosphotransferase; $P 35 S=$ promoter of cauliflower mosaic virus; nos $=3$ 'signal of nopaline synthase; $M A R=$ tobacco $\mathrm{Rb}_{7}$ matrix attachment regions; AmAl= Amaranth albumin gene; $p G t 1=$ rice glutelin $G t 1$ promoter; $L B 1, R B 1=$ left and right borders of the first T-DNA region; $L B 2, R B 2=$ left and right borders of the second T-DNA region. As indicated in the figure, a full length fragment of $h p t$ or AmAl coding region was used as a probe.

$\mathrm{kb}$ tobacco $\mathrm{Rb}_{7}$ matrix attachment regions (MARs) for high-level transgene expression in rice (23), the other T-DNA region carrying a hygromycin resistance gene (hpt) driven by Cauliflower mosaic virus (CaMV 35S) promoter. The pCDMAR-AmA1-hpt was transferred into Agrobacterium tumefaciens strain EHA105 by the freeze-thaw method (24), for use in rice transformation as follows.

\subsection{Rice Transformation and Regeneration}

An elite indica rice variety 'MH86' (obtained from Rice Research Institute, Fujian Academy of Agricultural Sciences), was selected as the target plant in this study. Agrobacterium-mediated rice transformation, selection, and plant generation were performed following the procedure described by $\mathrm{Su}$ et al. (25). Briefly, embryogenic calli were induced from sterilized immature embryos (12-15 d after pollination) on NB media containing $2.0 \mathrm{mg} . \mathrm{L}^{-1} 2,4-$ D. After a 4-d pre-incubation on fresh NB media, rice calli were soaked in the suspension culture of $A$. tumefaciens carrying pCDMAR-AmA1-hpt for $30 \mathrm{~min}$, followed by the removal of excess broth by the sterile filter paper, transferred to the Co-medium plus $100 \mu \mathrm{M}$ acetosyringone, and incubated in dark at $25{ }^{\circ} \mathrm{C}$ for 3 d. Co-cultivated rice calli were washed with sterile water supplemented with $250 \mathrm{mg} \cdot \mathrm{L}^{-1}$ carbenicillin and placed on selection medium containing $30 \mathrm{mg} . \mathrm{L}^{-1}$ hygromycin and $250 \mathrm{mg} . \mathrm{L}^{-1}$ carbenicillin. After twomonth selection, resistant calli were regenerated and transferred to regeneration medium containing $2 \mathrm{mg} . \mathrm{L}^{-1}$ 6-BA and $\left.0.5 \mathrm{mg} \cdot \mathrm{L}^{-1} \mathrm{NAA}\right)$. Shooting buds of about 3 $\mathrm{cm}$ were cut and further cultured on $1 / 2 \mathrm{MS}$ medium containing $30 \mathrm{mg} . \mathrm{L}^{-1}$ hygromycin for root development. After hygromycin-resistant T0 plantlets were welldeveloped, they were transferred to pots with soil for further growth and maturity. 


\subsection{Nucleic Acid Analysis}

Total genomic DNA was isolated from the leaves of transgenic rice with plant mini-genomic DNA isolation Kit (Dingguo, China) for polymerase chain reaction (PCR) analysis. Two sets of primer pairs, including A1 (5'-ATGGCGGGATTACCAGTG-3') and A2 (5'-TTAGTTGTTGGATCCCAATTC-3') for AmAl, and $\mathrm{H} 1$ (5'-CTATTTCTTTGCCCTCGGAC-3') and H2 (5'-AAGCCTGAACTCACCGCGAC-3') for $h p t$ were designed for PCR analyses using the Primer Premier 5.0 software. The PCR conditions of AmAl amplification were: $94{ }^{\circ} \mathrm{C}$ for $5 \mathrm{~min}$, followed by 30 cycles of $94{ }^{\circ} \mathrm{C}(40 \mathrm{~s}), 56{ }^{\circ} \mathrm{C}(40 \mathrm{~s})$, and $72{ }^{\circ} \mathrm{C}(1 \mathrm{~min})$. The conditions of $h p t$ gene amplification were: $94^{\circ} \mathrm{C}$ for $5 \mathrm{~min}$, followed by 30 cycles of $94{ }^{\circ} \mathrm{C}(40 \mathrm{~s}), 58^{\circ} \mathrm{C}(40$ $\mathrm{s})$, and $72{ }^{\circ} \mathrm{C}(1 \mathrm{~min})$. The PCR products were analyzed by electrophoresis on $1 \%$ agarose gel and imaged with a gel imaging system (Bio-RAD, U.S).

In Southern blot, genomic DNA was extracted from $5 \mathrm{~g}$ leaf tissues using the CTAB method (26). A $10 \mu \mathrm{g}$ aliquot of genomic DNA was digested with suitable restriction endonuclease and separated on a $0.8 \%$ agarose gel. Following electrophoresis, the DNA fragments were transferred onto a nylon membrane (Amersham, UK) with the aid of an alkaline solution (0.4 M NaOH, $1.5 \mathrm{M} \mathrm{NaCl})$. The hpt and AmAl probes were synthesized using the PCR DIG Probe Synthesis Kit (Roche, Swiss) and hybridization assay was performed in accordance with the protocol from DIG High Prime of DNA Labeling and Detection Starter Kit I (Roche, Swiss).

Total RNA samples were isolated from each developed rice seed 12-15 days after flowering using EASY spin plant RNA kit (Aidlab, China) and reverse-transcribed into cDNA as a template for realtime quantitative reverse transcription PCR (qRTPCR). The gene-specific primer sets for $A m A 1$ were: 5'-CGAACCTTCCAAGACTTATGATG-3' and 5'-TGGCTGATGCTGTAATCCA-3' and rice actin 1 was used as the reference gene to normalize targeted gene expression. The qRT-PCR was performed in a $20 \mu \mathrm{L}$ reaction volume with $0.5 \mu \mathrm{M}$ each primer and $2 \times$ SYBR Green real-time PCR master mix (Takara, Japan). The reactions were run on ABI 7500 Real-Time PCR System using the cycling conditions described by Huang et al. (27). The relative expression of the $A m A 1$ was $\mathrm{RQ}=2^{-\Delta \Delta \mathrm{Ct}}$. Each sample was amplified in triplicate.

\subsection{Antibody Preparation}

The prokaryotic expression vector pET28-AmA1 previously constructed (21) and the molecular chaperone vector of E. coli: pBB540, pBB542 (containing groES and the groEL, was a gift from Dr. Ario de Macro of EMBL) were co-transformed into BL21 (DE3) competent cells to obtain the recombinant strain BL21 (DE3)/pET28a-AmA1-C4. It was then cultured on LB medium containing $30 \mu \mathrm{g} \cdot \mathrm{mL}^{-1}$ kanamycin, $34 \mu \mathrm{g} \cdot \mathrm{mL}^{-1}$ chloramphenicol and $50 \mu \mathrm{g} \cdot \mathrm{mL}^{-1}$ spectinomycin and grown to the $\mathrm{OD}_{600} 0.6$. IPTG was added at a final concentration of $0.4 \mathrm{mM}$, and the culture was shaken at $20{ }^{\circ} \mathrm{C}$ for $10 \mathrm{~h}$. Bacterial cells were collected and broke open to use the cell lysate to pass through Ni-NTA Histag purification resin (Biomiga, U.S) in order to purify the AmA1 recombinant fusion protein. The protein samples were collected by ultrafiltration (Millipore, U.S) and sent to the Animal Center of the Institute of Zoology, Chinese Academy of Sciences, to make the rat immune polyclonal antibody.

\subsection{Protein Extraction and Western Blotting}

Albumin protein was extracted from the transgenic rice seeds according to Schaeffer and Sharpe (28). The appropriate protein samples with $2 \times$ buffer solution (100 mM Tris- $\mathrm{HCl}$ with $\mathrm{pH} \quad 6.8,200 \mathrm{mM}$ DDT, 4\% $\mathrm{w} / \mathrm{v}$ SDS, $20 \% \mathrm{v} / \mathrm{v}$ glycerol, $0.2 \% \mathrm{w} / \mathrm{v}$ bromophenol blue R) were mixed and denatured at $99{ }^{\circ} \mathrm{C}$ for 10 min. Electrophoretic separation was performed on a polyacrylamide gel containing $12 \%$ separating gel and $5 \%$ stacking gel, and the protein bands were stained with Coomassie Brilliant Blue R-250. Trans-blot SD semi-dry electrophoretic transfer cell device (BioRAD, U.S) was used to transfer proteins to PVDF membranes. Rat anti-AmA1 antiserum was used as the first antibody, and goat anti-rat IgG-HRP conjugate was used as the secondary antibody (CWBIO, China). Protein bands were visualized in 3,3'-diaminobenzidine (DAB) substrate solution (CWBIO, China).

\subsection{Protein, Amino acid, and Thousand-grain Weight (TGW) Analysis}

Total protein content and amino acid composition of mature seeds from T2 homozygous transgenic lines and wild-type plant were analyzed in the Central Laboratory of the Fujian Academy of Agricultural Sciences, China. Protein content was measured by the Kjeldahl method, using a conversion factor of 5.95. Amino acid content was measured by high-speed amino acid analyzer (Hitachi L-8800, Japan). TGW was determined by counting 500 grains with the automatic seed counter (SLY-A,China), weighing the sample and evaluating the respective TGW. 


\subsection{Statistical Analysis}

Measurements of protein content, amino acid content, and TGW were carried out in triplicate. Comparison of mean values from different data sets was analyzed for statistical significance with the Student's $\boldsymbol{t}$-test.

\section{Results}

\subsection{Generation of Co-transformed Rice Containing Both hpt and AmA1}

A total of 19 independent promising T0 transgenic rice plantlets (denoted from GA1 to GA19) were regenerated from 24 hygromycin-resistance calli within approximately 6-month of beginning of the culture.

PCR analysis by a pair of specific primers, $\mathrm{H} 1$ and $\mathrm{H} 2$, on the hpt gene in the T0 generation indicated that products of about $1018 \mathrm{bp}$ were amplified from the genomic DNA of all of the transgenic plants and the positive control (plasmid as a template), whereas no band was detected in wild-type plant (Fig. 2A). The second pair of primers, A1 and A2 was used to identify whether the lines carried the AmAl (915 bp) The PCR revealed that 6 out of 19 plants were transgenic (Fig. 2B; co-transformation frequency $=31.5 \%$ ).

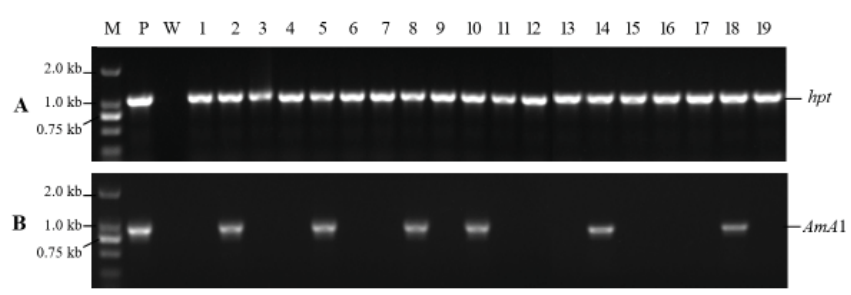

Figure 2. PCR analysis of T0 transfromants for $h p t$ and AmAl genes. A. PCR amplification of the hpt gene; B. PCR amplification of the AmAl gene; $\mathrm{M}=$ molecular marker DL2000; $\mathrm{P}=$ plasmid pCDMARAmA1-hpt; $\mathrm{W}=$ wild type plant; 1-19= different transgenic plants.

The six co-transformed T0 plants were further identified by Southern blot, wherein DIG-labeled AmAl was used as the probe. The Southern result confirmed the PCR results (Fig. 3). According to the hybridization signals shown in Figure 3, the size and number of hybridization bands both varied differently among the transgenic plants, indicating that the target gene was integrated in different genomics sites of the rice transgenic lines.

\subsection{Selection of SMG-free, Homozygous Transgenic Lines}

To obtain SMG-free plants, the six T0 co-transformants were planted in the greenhouse and allowed to self-
GA2 GA5 GA8 GA10 GA14 GAl8 WT P

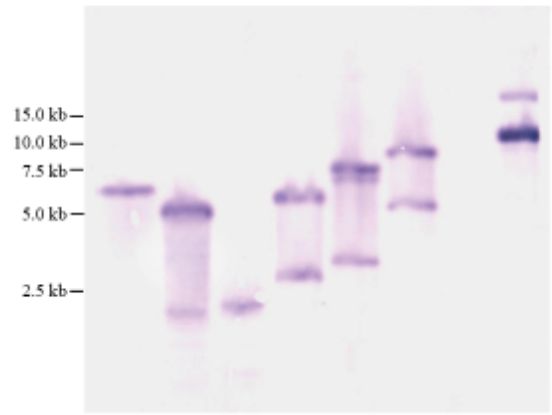

Figure 3. Southern blot analysis of T0 co-transformants. WT= wild type plant; $\mathrm{P}=$ plasmid pCDMAR-AmA1-hpt. Genomic DNAs were digested with $B g l$ II and hybridized with the DIG-labeled AmAl coding sequence.

pollinate. The total DNA was extracted from the T1 seedlings for both PCR and Southern analyses. As shown in Figure 4, the plants in lanes 4, 10 and 11 were positive for the AmAl, but negative for the hpt gene
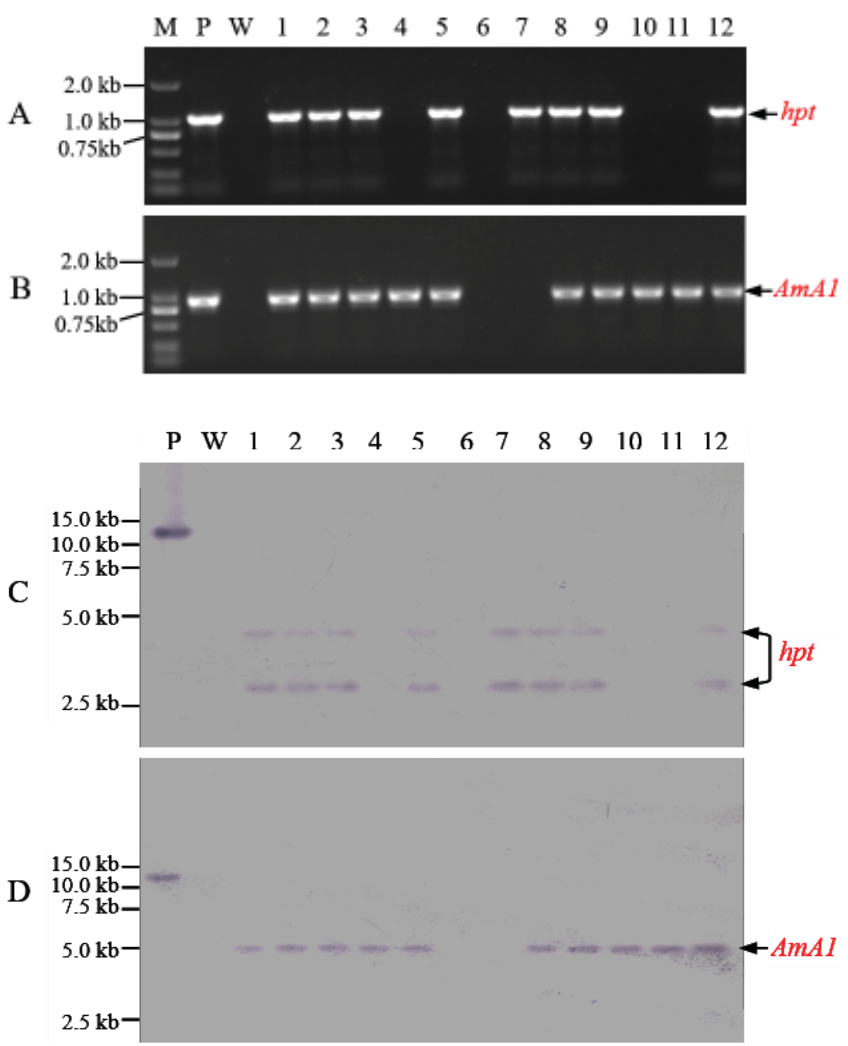

Figure 4. PCR and Southern blotting analyses of $\mathrm{T} 1$ progenies from $\mathrm{T} 0$ co-transformants GA8. A. PCR amplification of the AmA1 gene; B. PCR amplification of the hpt gene; C. Southern blotting analysis for the $h p t$ gene; D. Southern blotting analysis for the AmAl gene; $\mathbf{M}=$ molecular marker DL2000; $\mathrm{P}=$ plasmid pCDMAR-AmA1-hpt; $l \mathrm{~W}=$ wild type plant; $1-12=$ different transgenic individual plants of $\mathrm{T} 1$ progenies from T0 co-transformants GA8. Genomic DNA digested with HindIII was loaded in each lane. 
Xu M et al.

Table 1. Segregation of $A m A 1$ and $h p t$ in T1 plants

\begin{tabular}{|c|c|c|c|c|c|c|}
\hline \multirow{2}{*}{$\begin{array}{c}\text { T0 Co- } \\
\text { transformants }\end{array}$} & \multicolumn{5}{|c|}{ T1 progenies screened by PCR analysis } & \multirow{2}{*}{$\begin{array}{l}\text { Frequency of SMG-free } \\
\text { transgenic plant }(\%)\end{array}$} \\
\hline & $\begin{array}{l}\text { Total } \\
\text { number }\end{array}$ & $A m A 1^{+} h p t$ & $A m A 1-h p t^{+}$ & $A m A 1^{+} h p t^{+}$ & AmA1'hpt & \\
\hline GA2 & 60 & 9 & 3 & 40 & 8 & 15.0 \\
\hline GA5 & 73 & 22 & 2 & 48 & 1 & 30.1 \\
\hline GA8 & 72 & 28 & 4 & 38 & 2 & 38.8 \\
\hline GA10 & 56 & 10 & 6 & 35 & 5 & 17.8 \\
\hline GA14 & 48 & 0 & 0 & 48 & 0 & 0 \\
\hline GA18 & 76 & 5 & 9 & 59 & 3 & 6.6 \\
\hline Total & 385 & 74 & 24 & 268 & 19 & - \\
\hline
\end{tabular}

and ${ }^{-}$mean positive and negative in PCR detection, respectively.

$\left(A m A 1^{+} h p t\right)$, appearing as the SMG-free transgenic events. Then, 74 SMG-free plants derived from five T0 co-transformants (GA2, GA5, GA8, GA10, GA18) were segregated from $385 \mathrm{~T} 1$ progeny and the frequency of SMG-free plant differed among the five co-transformants, the highest reaching $38.8 \%$ in GA8 and the lowest only $6.6 \%$ in GA18 (Table 1 ). No SMGfree plant was found in $\mathrm{T} 1$ progenies of line GA14.

Further, five SMG-free plants were chosen randomly from each line of $\mathrm{T} 1$ generation and grown in the restricted greenhouse. Their DNA was screened to find homozygous transgenic lines via PCR. It was shown that five T2 transgenic plants, GA2-2, GA5-10, GA85, GA10-2, GA18-7, were identified as putative SMGfree, homozygous transgenic lines. Subsequently, T3 progenies derived from these homozygous T2 lines showed 100\% PCR positive for AmAl (data not shown).

\subsection{Expression of AmA1 in Transgenic Rice Seed}

Real-time PCR analysis showed that the AmAl transcripts were present at variable levels in the developing seeds of $\mathrm{T} 2$ generation homozygous lines, GA2-2, GA5-10, GA8-5, GA10-2, GA18-7. The highest

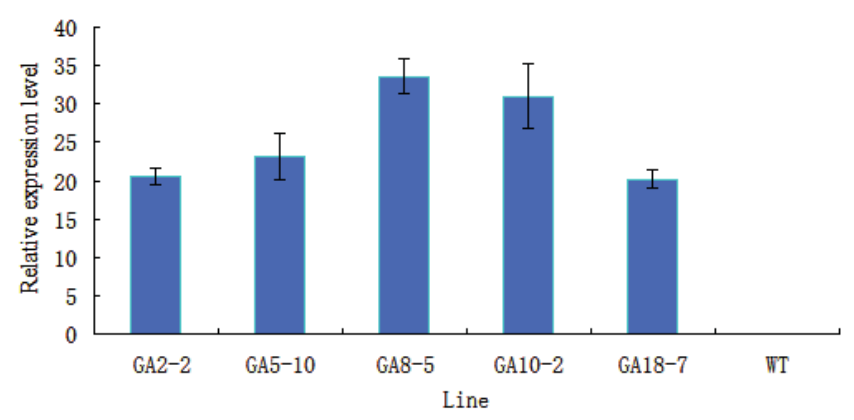

Figure 5. Real-time PCR analysis of AmA1 expression in transgenic rice seeds. $\mathrm{WT}=$ wild type plant. transcription level was measured in line GA8-5 and no AmA1 transcripts were found in wild type plant (Fig. 5).

To detect the accumulation of AmA1 in transgenic rice seeds, albumin proteins extracted from $\mathrm{T} 2$ generation seeds of five homozygous lines were subjected to SDS-PAGE and Western blotting. The SDSPAGE separation showed a band of $35 \mathrm{kDa}$ in all five transgenic lines, while, as expected, there was no signal detectable in wild type plant (Fig. 6A). Presence of the $35 \mathrm{kDa}$ large polypeptide of AmA1 in the transgenic rice seeds was further confirmed by immuno-detection with the polyclonal anti-AmA1 antibody using a HRP conjugated secondary antibody (Fig. 6B). The results showed that AmA1 was accumulated in the T2 seeds of the five homozygous transgenic lines.

\subsection{Increase of Both Protein and EAA Contents in Transgenic Rice Seed}

Mature T2 seeds, which collected from the five marker-

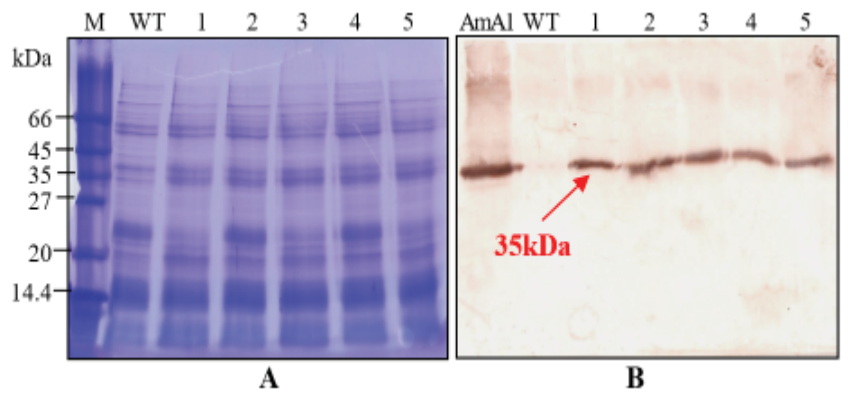

Figure 6. SDS-PAGE and western blot analysis of AmA1 in transgenic rice seed. A. SDS-PAGE patterns of the albumin fractions in transgenic rice seed samples. B. Western blotting of the protein extracted from the same seeds. 1-5= transgenic lines GA2-2, GA5-10, GA8-5, GA10-2, GA18-7; M= protein marker; WT= wild type; AmA1 = albumin proteins extracted from seed of Amaranthus hypochondriacus. 
Xu M et al.

Table 2. Protein content (\%) and TGW (g) of transgenic rice with $A m A 1$

\begin{tabular}{ccccc}
\hline $\begin{array}{c}\text { Homozygous } \\
\text { transgenic lines }\end{array}$ & $\begin{array}{c}\text { Total protein content } \\
\left(\mathbf{g} . \mathbf{1 0 0} \mathbf{g}^{-1} \mathbf{D W}\right)\end{array}$ & $\begin{array}{c}\text { Increase of total } \\
\text { protein content } \mathbf{( \% )}\end{array}$ & TGW (g) & $\begin{array}{c}\text { Decrease of TGW } \\
\mathbf{( \% )}\end{array}$ \\
\hline GA2-2 & $8.56 \pm 0.20^{\mathrm{ns}}$ & 1.06 & $23.78 \pm 0.30^{* *}$ & 5.63 \\
GA5-10 & $9.48 \pm 0.23^{* *}$ & 11.92 & $22.95 \pm 0.20^{* *}$ & 8.93 \\
GA8-5 & $9.56 \pm 0.23^{* *}$ & 12.87 & $24.33 \pm 0.31^{*}$ & 3.45 \\
GA10-2 & $8.85 \pm 0.27^{\mathrm{ns}}$ & 4.49 & $21.68 \pm 0.48^{* *}$ & 13.97 \\
GA18-7 & $8.77 \pm 0.31^{\mathrm{ns}}$ & 3.54 & $22.22 \pm 0.47^{* *}$ & 11.83 \\
WT & $8.47 \pm 0.09$ & - & $25.20 \pm 0.15$ & - \\
\hline
\end{tabular}

Values are presented as the mean $\pm \mathrm{SE}$; ${ }^{*}$ and ${ }^{* *}$ mean the least significant differences at 0.05 and 0.01 probability levels, respectively, when compared with the wild types; ns: not significant; WT: the wild type.

free, homozygous transgenic lines were subjected to analyses of crude protein, TGW and EAA contents. It was shown that the total protein content varied from $8.56 \%$ to $9.56 \%$ and showed an increase by $1.06 \%$ to $12.87 \%$ in compared with wild type control (Table 2). Whereas, the TGW of these transgenic lines decreased at different levels $(5.63 \sim 13.97 \%)$ and no obvious correlation was found between the protein content and the TGW (Table 2).

The increase in total protein content was accompanied by the increase of seven EAAs content compared to the wild type control (Table 3 ). The highly expressed line
(GA8-5) showed a significant content increase of $10.8 \%$ and $9.1 \%$ for lysine and threonine, respectively. In addition, the contents of several other EAAs, including valine, isoleucine, leucine and phenylalanine, were also increased by $14.6 \%, 12.1 \%, 14.7 \%$ and $15.6 \%$, respectively (Table 3 ).

\section{Discussion}

It has been demonstrated that the twin T-DNA vector system, involving transforming with one binary vector having two T-DNAs, one containing SMG and one gene of interest (GOI), is successful in producing

Table 3. EAA content of transgenic rice seed with AmAl

\begin{tabular}{ccccccc}
\hline \multirow{2}{*}{ EAAs } & \multicolumn{5}{c}{ EAA content $\left(\mathbf{g . 1 0 0} \mathbf{g}^{-1}\right.$ seed dry weight) } \\
\cline { 2 - 6 } & WT & Line GA2-2 & Line GA5-10 & Line GA8-5 & Line GA10-2 & Line GA18-7 \\
\hline \multirow{2}{*}{ Lysine } & $0.37 \pm 0.01$ & $0.39 \pm 0.01^{\mathrm{ns}}$ & $0.40 \pm 0.02^{*}$ & $0.41 \pm 0.02^{*}$ & $0.38 \pm 0.01^{\mathrm{ns}}$ & $0.38 \pm 0.01^{\mathrm{ns}}$ \\
& & $(5.4)$ & $(8.1)$ & $(10.8)$ & $(2.7)$ & $(2.7)$ \\
Threonine & $0.33 \pm 0.01$ & $0.33 \pm 0.01$ & $0.36 \pm 0.02^{\mathrm{ns}}$ & $0.36 \pm 0.01^{*}$ & $0.34 \pm 0.01^{\mathrm{ns}}$ & $0.34 \pm 0.01^{\mathrm{ns}}$ \\
& & $(0)$ & $(9.1)$ & $(9.1)$ & $(3.0)$ & $(3.0)$ \\
Methionine & $0.15 \pm 0.01$ & $0.15 \pm 0.01$ & $0.17 \pm 0.01^{\mathrm{ns}}$ & $0.16 \pm 0.01^{\mathrm{ns}}$ & $0.16 \pm 0.00^{\mathrm{ns}}$ & $0.16 \pm 0.01^{\mathrm{ns}}$ \\
& & $(0)$ & $(13.3)$ & $(6.7)$ & $(6.7)$ & $(6.7)$ \\
Valine & $0.48 \pm 0.02$ & $0.48 \pm 0.02$ & $0.54 \pm 0.01^{* *}$ & $0.55 \pm 0.02^{*}$ & $0.50 \pm 0.01^{\mathrm{ns}}$ & $0.50 \pm 0.00^{\mathrm{ns}}$ \\
& & $(0)$ & $(12.5)$ & $(14.6)$ & $(4.2)$ & $(4.2)$ \\
isoleucine & $0.33 \pm 0.01$ & $0.33 \pm 0.01$ & $0.37 \pm 0.00^{* *}$ & $0.37 \pm 0.00^{* *}$ & $0.34 \pm 0.01^{\mathrm{ns}}$ & $0.34 \pm 0 . .^{01 \mathrm{~ns}}$ \\
& & $(0)$ & $(12.1)$ & $(12.1)$ & $(3.0)$ & $(3.0)$ \\
Leucine & $0.68 \pm 0.03$ & $0.68 \pm 0.02$ & $0.76 \pm 0.02^{*}$ & $0.78 \pm 0.03^{*}$ & $0.72 \pm 0.01^{\mathrm{ns}}$ & $0.71 \pm 0.02^{\mathrm{ns}}$ \\
& & $(0)$ & $(11.8)$ & $(14.7)$ & $(5.9)$ & $(4.4)$ \\
Phenylalanine & $0.45 \pm 0.01$ & $0.46 \pm 0.01^{\mathrm{ns}}$ & $0.51 \pm 0.02^{* *}$ & $0.52 \pm 0.01^{* *}$ & $0.48 \pm 0.01^{* *}$ & $0.47 \pm 0.01^{\mathrm{ns}}$
\end{tabular}

Values are presented as the mean $\pm \mathrm{SE}$; amino acid increase (\%) in transgenic rice in relation to wild type is presented in parentheses; * and ${ }^{* *}$ mean the least significant differences at 0.05 and 0.01 probability levels, respectively, when compared with the wild types; ns: not significant; WT: the wild type. 
SMG-free transformants at reasonable frequencies (19). Yu et al. (29) and Jiang et al. (30) achieved the co-transformation frequency of $29.87 \%$ and $43.8 \%$, respectively, when rice was transformed with the twin T-DNA vector system. Sun et al. (31), working on chrysanthemum, also employed twin T-DNA vector system and reported a co-transformation frequency of $38.4 \%$. Our co-transformation frequency $(31.5 \%)$ was comparable to those obtained by other groups (29-31).

In a co-transformation experiment, when the two separate T-DNAs integrate at unlinked sites in the host genome, the gene of interest can segregate away from SMG in successive generations and SMG-free plants were subsequently obtained $(19,29)$. In this study, from 6 lines transformed with the AmAl and $h p t$, segregation occurred in 5 lines only contained AmAl gene, indicating an isolation frequency of SMGfree lines of about $83.3 \%$ among co-transformants. This is much higher than the previous studies $(1,29$, $30,32)$, this is perhaps due to factors such as different receptor and integrated position of targeted gene in the receptor genome. Similar results were observed in co-transformation experiment conducted by $\mathrm{Hou}$ et al. (33), which showed 12 out of 13 indica rice cotransformants displayed a segregation of the SMG and target gene in $\mathrm{T} 1$ generation, using nearly the same twin T-DNA binary vector system as in the current study. No SMG-free plant was found in T1 progenies of line GA14, this might be caused by the integration of both the AmAl and $h p t$ genes at linked loci.

To date, genetic engineering technology has been used to modify the amino acid composition of rice proteins and several transgenic strategies have been developed $(4,6)$, among which, the most common strategy is to transfer and over-express the gene encoding a heterologous or homologous protein being rich in a desirable EAA into rice $(1,4,6,8,11,34)$. The key factor contributing to the success of this approach is the availability of candidate EAA-rich protein genes and appropriate regulatory elements such as a seed-specific promoter and a signal peptide sequence.

The AmA1 from A. hypochondriacus is a wellbalanced protein in terms of amino acid composition and even better than the values recommended by the World Health Organization for a nutritionally rich protein (13). More importantly, AmA1 is a non-allergenic protein in its purified form (15). Previous studies on AmA1 have shown that its cDNA can be expressed successfully in wheat grains (16) and potato tubers $(14,15)$, exhibiting a remarkable increases in most EAAs of transgenic lines. These findings demonstrate the feasibility of using the $A m A 1$ gene in genetic engineering to improve the nutritive value of crops.

The Gt1 promoter used in this study is endospermspecific and strongly expressed in the outer endosperm, which had been demonstrated with the GUS reporter gene in transgenic rice (35). Many proteins have been successfully expressed in rice seeds using Gt1 promoter such as bean seed storage protein $\beta$-phaseolin for improving the nutritional quality of rice grains (36), human lactoferrin for use in infant formula (37), and CALB as a biocatalyst for biodiesel production (38). As expected in this study, AmA1, an EAA-rich seed storage protein, was successfully expressed and accumulated in transgenic rice grains under the control of rice Gt1 promoter, with a significant increasing in both protein content and most EAAs contents. It might be that the decrease of total protein affected the starch accumulation during rice grain development, and consequently the TGWs of most transgenic lines dropped considerably. As an important factor related to rice grain yield potential (39), TGW decrease will have negative effects on the total protein biomass in large scale production (38). Nevertheless, a transgenic line (GA8-2) was obtained, which had highest increase in both protein content and most EAAs content, but only slight decrease in thousand-grain weight $(3.45 \%)$. The next step of the research will focus on assessment of the major agronomic characters of line GA8-2 in field and digestibility of AmA1 in the transgenic rice seed.

\section{Acknowledgments}

We thank Dr. Shiqiang Lin for technical assistance on preparing antibody against AmA1. We would also thank Dr. Chengkun He for kindly providing tobacco $\mathrm{Rb}_{7}$ MARs. This work was supported by the National Transgenic Organism New Variety Key Project (2009ZX08001-032B), the Science and Technology Innovation Fund of FAFU(CXZX2016156) and the Science \& Technology Innovation Platform Development Program of FAFU (PTJH13001, PTJH12015).

\section{References}

1. Kusano M, Yang Z, Okazaki Y, Nakabayashi R, Fukushima A, Saito K. Using metabolomic approaches to explore chemical diversity in rice. Mol Plant. 2015;8(1):58-67. DOI: 10.1016/j. molp.2014.11.010.

2. Miura K, Ashikari M, Matsuoka M. The role of QTLs in the breeding of high-yielding rice. Trends Plant Sci. 2011;16(6):319326. DOI: 10.1016/j.tplants.2011.02.009.

3. Juliano BO. Rice: Chemistry and Technology. Minnesota, USA: Inc., St. Paul; 1985. p. 1-174. 
4. Ufaz S, Galili G. Improving the content of essential amino acids in crop plants: goals and opportunities. Plant Physiol. 2008;147(3):954-961. DOI: 10.1104/pp.108.118091.

5. Birla DS, Malik K, Sainger M, Chaudhary D, Jaiwal R, Jaiwal PK. Progress and Challenges in Improving the Nutritional Quality of Rice (Oryza sativa L.). Crit Rev Food Sci Nutr. 2015:0. DOI: 10.1080/10408398.2015.1084992.

6. Sun SSM, Liu Q. Transgenic approaches to improve the nutritional quality of plant proteins. In Vitro Cell Dev-Pl. 2004;40(2):155-162. DOI: 10.1079/ivp2003517.

7. Zhu C, Naqvi S, Gomez-Galera S, Pelacho AM, Capell T, Christou P. Transgenic strategies for the nutritional enhancement of plants. Trends Plant Sci. 2007;12(12):548-555. DOI: 10.1016/j.tplants.2007.09.007.

8. Sindhu AS, Zheng ZW, Murai N. The pea seed storage protein legumin was synthesized,processed and accumulated stably in transgenic rice endosperm. Plant Sci. 1997;130(2):189-196. DOI:10.1016/S0168-9452(97)00219-7.

9. Gao YF, Jing YX, Shen SH, Tian SP, Ting KY, Sun SSM. Transfer of lysine-rich protein gene intorice and poduction of fertile transgenic plants. Acta Botanica Sinica. 2001;43(4):506511. DOI:10.3321/j.issn:1672-9072.2001.05.010.

10. Wang WM, Zhao Q, Yu JJ, Zhu DY, Ao GM. Transfer of high lysine gene $s b 401$ into rice and analysis for protein and amino acid content in transgenic rice seeds. Acta Agron Sin. 2005;31(5):603-607. DOI:10.3321/j.issn:04963490.2005.05.013.

11. Hagan ND, Upadhyaya N, Tabe LM, Higgins TJV. The redistribution of protein sulfur in transgenic rice expressing a gene for a foreign, sulfur-rich protein. Plant J. 2003;34(1):1-11. DOI: 10.1046/j.1365-313X.2003.01699.x.

12. Lee TT, Wang MM, Hou RC, Chen LJ, Su RC, Wang CS, et al. Enhanced methionine and cysteine levels in transgenic rice seeds by the accumulation of sesame $2 \mathrm{~S}$ albumin. Biosci Biotechnol Biochem. 2003;67(8):1699-1705. DOI: 10.1271/ bbb.67.1699.

13. Raina A Datta. Molecular cloning of a gene encoding a seed-specific protein with nutritionally balanced amino acid composition from Amaranthus. Proc Natl Acad Sci USA. 1992;89:11774-11778. DOI: 10.1073/pnas.89.24.11774.

14. Chakraborty S, Chakraborty N, Datta A. Increased nutritive value of transgenic potato by expressing a nonallergenic seed albumin gene from Amaranthus hypochondriacus. Proc Natl Acad Sci USA. 2000;97(7):3724-3729. DOI: 10.1073/ pnas.050012697.

15. Chakraborty S, Chakraborty N, Agrawal L, Ghosh S, Narula $\mathrm{K}$, Shekhar S, et al. Next-generation protein-rich potato expressing the seed protein gene AmA1 is a result of proteome rebalancing in transgenic tuber. Proc Natl Acad Sci USA. 2010;107(41):17533-17538. DOI: 10.1073/pnas.1006265107.

16. Tamás C, Kisgyörgy BN, Rakszegi M, Wilkinson MD, Yang $\mathrm{M}-\mathrm{S}$, Láng L, et al. Transgenic approach to improve wheat (Triticum aestivum L.) nutritional quality. Plant Cell Rep. 2009;28(7):1085-1094. DOI: 10.1007/s00299-009-0716-0.

17. Ramessar K, Peremarti A, Gómez-Galera S, Naqvi S, Moralejo $\mathrm{M}$, Muñoz $\mathrm{P}$, et al. Biosafety and risk assessment framework for selectable marker genes in transgenic crop plants: a case of the science not supporting the politics. Transgenic Res. 2007;16(3):261-280. DOI: 10.1007/s11248-007-9083-1.

18. Oliva N, Chadha-Mohanty P, Poletti S, Abrigo E, Atienza $\mathrm{G}$, Torrizo L, et al. Large-scale production and evaluation of marker-free indica rice IR64 expressing phytoferritin genes.
Mol Breeding. 2014;33(1):23-37. DOI: 10.1007/s11032-0139931-z.

19. Yau Y-Y, Stewart CN. Less is more: strategies to remove marker genes from transgenic plants. BMC Biotechnol. 2013;13(1):123. DOI: $10.1186 / 1472-6750-13-36$.

20. Gao X, Zhou J, Li J, Zou X, Zhao J, Li Q, et al. Efficient generation of marker-free transgenic rice plants using an improved transposon-mediated transgene reintegration strategy. Plant Physiol. 2015;167(1):11-24. DOI: 10.1104/ pp.114.246173.

21. Xu M, Yan QH, Huang ZW CZ, Yan QH, Zheng JG. Cloning, Prokaryotic expression and plant expression vector construction of AmA1 gene from Amaranthus hypochondriacus. Molecular Plant Breeding. 2009;7(4):531-536. DOI: 10.3969/ mpb.007.000531.

22. Takaiwa F, Ebinuma H, Kikuchi S, Oono K. Nucleotide sequence of a rice glutelin gene. FEBS Lett. 1987;221(1):43-47. DOI: 10.1016/0014-5793(87)80349-6.

23. Verma D, Verma M, Dey M, Jain RK, Wu R. Molecular dissection of the tobacco $R b 7$ matrix attachment region (MAR): Effect of $5^{\prime}$ half on gene expression in rice. Plant Sci. 2005;169(4):704711. DOI: 10.1016/j.plantsci.2005.05.021.

24. Höfgen R, Willmitzer L. Storage of competent cells for Agrobacterium transformation. Nucleic Acids Res. 1988;16(20):9877. DOI: 10.1093/nar/16.20.9877.

25. Su J, Hu CQ, Zhai HL, Yan JW.Chen XJ, Wang F. Establishment of a highly efficient and stable tranforming system mediated by Agrobacterium tumefacien in indica rice. Fujian J Agricul Sci. 2003;18(4):209-213.

26. Murray MG, Thompson WF. Rapid isolation of high molecular weight plant DNA. Nucl Acids Res. 1980;8(19):4321-4326. DOI: $10.1093 / \mathrm{nar} / 8.19 .4321$.

27. Huang Z, Lin J, Cheng Z, Xu M, Guo M, Huang X, et al. Production of oleanane-type sapogenin in transgenic rice via expression of $\beta$-amyrin synthase gene from Panax japonicus C. A. Mey. BMC Biotechnol. 2015;15(1):1-8. DOI: 10.1186/ s12896-015-0166-4.

28. Schaeffer WG, Sharpe TF. Electrophoretic profiles and amino acid composition of rice endosperm proteins of a mutant with enhanced lysine and total protein after backcrosses for germplasm improvements. Theor App Genet. 1997;95(1):230235. DOI: $10.1007 / \mathrm{s} 001220050553$.

29. Yu H, Yao Q, Wang L, Zhao Z, Gong Z, Tang S, et al. Generation of selectable marker-free transgenic rice resistant to chewing insects using two co-transformation systems. Prog Nat Sci. 2009;19(11):1485-1492. DOI: 10.1016/j.pnsc.2009.04.005.

30. Jiang Y, Sun L, Jiang M, Li K, Song Y, Zhu C. Production of marker-free and RSV-resistant transgenic rice using a twin T-DNA system and RNAi. J Bioscience. 2013;38(3):573-581. DOI: $10.1007 / \mathrm{s} 12038-013-9349-0$.

31. Sun L, Zhou L, Lu M, CAI M, Jiang X-W, Zhang Q-X. MarkerFree Transgenic Chrysanthemum Obtained by AgrobacteriumMediated Transformation with Twin T-DNA Binary Vectors. Plant Mol Biol Rep. 2009;27(1):102-108. DOI: 10.1007/ s11105-008-0062-3.

32. Breitler J-C, Meynard D, Van Boxtel J, Royer M, Bonnot F, Cambillau L, et al. A Novel Two T-DNA Binary Vector Allows Efficient Generation of Marker-free Transgenic Plants in Three Elite Cultivars of Rice (Oryza sativa L.). Transgenic Res. 2004;13(3):271-287. DOI: 10.1023/B:TRAG.0000034626.229 18.0a.

33. Hou JL. Marker-free transgenic insect-resistance indica rice 


\section{$\mathbf{X u} \mathbf{M}$ et al.}

obtained by the vector carrying two separate T-DNAs. FuZhou, China: Fujian Agriculture and Forestry University; 2002. Master's Thesis.

34. Wong HW, Liu Q, Sun SSM. Biofortification of rice with lysine using endogenous histones. Plant Mol Biol. 2015;87(3):235248. DOI: 10.1007/s11103-014-0272-Z.

35. Zheng Z, Kawagoe Y, Xiao S, Li Z, Okita T, Hau TL, et al. 5' distal and proximal cis-acting regulator elements are required for developmental control of a rice seed storage protein glutelin gene. Plant J. 1993;4(2):357-366. DOI: $10.1046 / \mathrm{j} .1365-$ 313X.1993.04020357.x.

36. Zheng Z, Sumi K, Tanaka K, Murai N. The bean seed storage protein $\beta$-phaseolin is synthesized,processed,and accumulated in the vacuolar type-II protein bodies of transgenic rice endosperm. Plant Physiol. 1995;109(3):777-786. DOI:10.1104/ pp.109.3.777.

37. Nandi S, Suzuki YA, Huang J, Yalda D, Pham P, Wu L, et al. Expression of human lactoferrin in transgenic rice grains for the application in infant formula. Plant Sci. 2002;163(4):713-722. DOI: 10.1016/S0168-9452(02)00165-6.

38. Yang Y, Wang D, Zhang X, Fang J, Shen Z, Lin C. Transgenic rice as bioreactor for production of the Candida antarctica lipase B. Plant Biotechnol J. 2014;12(7):963-970. DOI: 10.1111/pbi.12204.

39. Yu S, Yang C, Fan Y, Zhuang J, Li X. Genetic dissection of a thousand-grain weight quantitative trait locus on rice chromosome 1. Chinese Sci Bull. 2008;53(15):2326-2332. DOI: 10.1007/s11434-008-0281-x. 